\title{
Intrapreneurial orientation in small and medium-sized enterprises: An exploration at the employee level
}

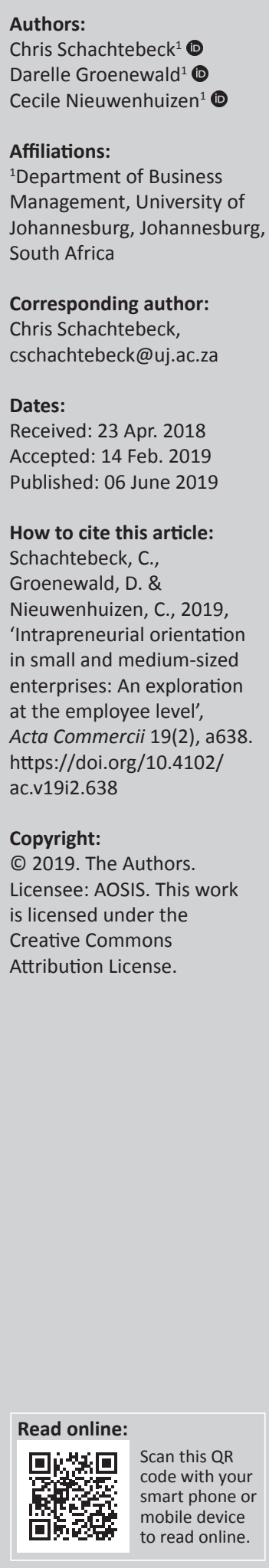

Orientation: The South African economy and, in particular, small and medium-sized enterprises (SMEs) have shown uninspiring performance, reflected in low levels of job creation, worryingly low levels of total early-stage entrepreneurial activity and entrepreneurial employee activity (EEA). As SMEs are the innovation and growth engine of an economy, the poor EEA levels $(0.7 \%)$ indicate lacklustre levels of innovation and intrapreneurial activity.

Research purpose: This study aims to fill the void by assessing the effect of intrapreneurial orientation $(\mathrm{IO})$ at the employee level on internal SME growth.

Motivation for the study: Despite this bleak outlook, to date no study has attempted to determine the influence of an IO on SME growth metrics.

Research design, approach and method: The study is quantitative in nature, using an adapted questionnaire and employing a random sampling approach. Data were analysed by means of factor, correlation and regression analyses. A total of 290 responses were received from SME employees across South Africa.

Main findings: The empirical study showed that only risk-taking, innovativeness, personal control, self-esteem and certain managerial factors positively relate to the growth of an SME.

Practical/managerial implications: The findings provide insights for managers within SMEs on improving employee entrepreneurial activity and growth rates, by means of focusing on growth-supportive IO interventions.

Contribution/value-add: The findings of this research are beneficial to academia and industry as the framework and measuring instrument offer additional insights into IO within SMEs.

Keywords: intrapreneurship; intrapreneurial orientation; South Africa; small and mediumsized enterprises; SMEs.

\section{Introduction}

Long regarded as the economic powerhouse of sub-Saharan Africa, South Africa has experienced social and economic turmoil in recent times. Gross domestic product (GDP) has declined in dollar terms since 2012, economic growth rates have slowed to near $1 \%$, unemployment rates have increased marginally, credit agencies have downgraded South Africa's credit ratings, while both exchange and inflation rates have been volatile (SEDA 2017; World Bank 2018). Small and medium-sized enterprises (SMEs) have long been touted as the solution to these socio-economic woes, with increasing reliance placed on entrepreneurs and SMEs to keep the economy buoyant, create new employment opportunities and thereby reduce unemployment (Herrington, Kew \& Mwanga 2017; SEDA 2017). The importance of SMEs can be seen in their economic significance; SMEs account for approximately $91 \%$ of formalised businesses in South Africa, providing $60 \%$ of employment opportunities to the labour force and contributing an estimated $34 \%$ of the GDP (Abor \& Quartey 2010; SEDA 2017).

Yet the South African SME sector has not lived up to the potential it holds for the economy at large, as the sector is experiencing difficulties of its own. The 2017 Global Entrepreneurship Monitor (GEM) points to South Africa as only one of three economies, besides Burkina Faso and Colombia, in which $15 \%$ of entrepreneurs expect to create no jobs at all because of a lack of growth and a subdued economic environment. The report further casts the spotlight on the country's low total early-stage entrepreneurial activity (TEA) rate of $6.9 \%$, which is among the 
lowest in sub-Saharan Africa (Herrington \& Kew 2017). The report further highlights the entrepreneurial quandary South Africa faces, with one of the lowest business ownership rates of only $2.5 \%$ among the GEM sample, as well as extremely low levels of entrepreneurial employee activity (EEA) at $0.7 \%$. Entrepreneurial employee activity can be regarded as an indicator of innovation and intrapreneurial activity within an organisation. Established organisations need to improve their EEA in order to harness the intrapreneurial potential of their employees, which is linked to innovation and superior performance (Herrington \& Kew 2017; World Economic Forum 2016). Spending on internal forms of innovation and entrepreneurial activity has declined in South Africa over the past decade, thereby impeding the emergence and growth of high-growth SMEs or 'gazelles' (Dessus, Goddard \& Hanusch 2017). Therefore, it is of utmost importance to create effective and sophisticated support systems that could foster entrepreneurship within organisations, thereby increasing the likelihood of growing 'gazelles'.

Intrapreneurship, most commonly termed corporate entrepreneurship (CE), has the potential to improve the performance of organisations, as confirmed by a number of studies (Bolton \& Lane 2012; Bosma, Stam \& Wennekers 2012; Brigić \& Umihanić 2015). While CE is most commonly associated with the 'top-down' approach of encouraging entrepreneurial activity, intrapreneurship tends to adopt the 'bottom-up' approach, where entrepreneurial actions are initiated and driven by employees themselves (Nyström 2012). The importance of employee-driven entrepreneurship is widely acknowledged, yet there is a significant lack of empirical research into this phenomenon, particularly with regard to the characteristics, attitudes and skills of the employee-intrapreneurs (Bosma et al. 2012; Nyström 2012). The entrepreneurial behaviour and actions, as initiated and driven by employees, are termed intrapreneurial orientation (IO) (Lyon, Lumpkin \& Dess 2000; Stewart 2009). It is concerning that only modest emphasis has been placed in current literature on employee-level characteristics encouraging employees to act as intrapreneurs, with only organisational-level variables featuring prominently in the existing literature (Antončič \& Hisrich 2001; Stull 2005; Vargas-Halabí, Mora-Esquivel \& Siles 2017). As a consequence of the scant literature on factors promoting intrapreneurship in organisations, the development of relevant research instruments and measures has been lagging (Slavec \& Drnovsek 2012). South Africa is no exception to this trend, with only limited investigation of the topic of IO. To date, no South African study has attempted to explore the effects of IO on internal organisational growth, framed within the context of the SME sector. This article therefore assesses employee-level IO and its effect on internal growth by utilising an adapted measuring instrument based on an integrated conceptual framework developed by Schachtebeck (2017).

\section{Key definitions}

Intrapreneurship for the purposes of this study can be defined as entrepreneurial behaviour within established organisations of any size (Antončič \& Hisrich 2003; Blundell \& Lockett 2011; Pinchot 1985).

Entrepreneurial orientation can be defined as 'the processes, practices and decision-making activities that lead to new entry' (Lumpkin \& Dess 1996:136). A similar concept, IO, makes reference to 'an individual employee's predisposition to accept entrepreneurial processes, practices and decisionmaking characterised by a preference for innovativeness, risk-taking and proactiveness' (Stewart 2009:29). Growth relates to absolute and relative growth measures, such as change in employee numbers, revenue and sales levels, profit, as well as number of customers (Gruber-Muecker \& Hofer 2015; Gürbüz \& Aykol 2009; Rodríguez- Gutiérrez, Moreno \& Tejada 2015; Shepherd \& Wiklund 2009; Urban 2012). Revenue levels differ from sales levels as revenue includes other income not attributable to sales. Number of customers as a growth measure refers to an absolute change in number of regular clients being serviced.

\section{Literature review and proposition formulation}

The following sections provide an overview of the theoretical underpinnings of the intrapreneurship and IO concepts as well as the integrated conceptual framework used in the study.

\section{Intrapreneurship}

Intrapreneurship, as an evolving field of research, is conceptually derived from entrepreneurial literature. However, the concept of intrapreneurship is intrinsically different from that of entrepreneurship. An entrepreneur is a person 'who organizes and operates a business through taking personal and financial risk', while an intrapreneur is 'an individual within an organization or company who creates and/or takes responsibility for transforming an idea into a profitable venture through taking an innovative approach' (Haller 2015:10). Intrapreneurship can also be seen as

a process in which an individual or group of individuals, within the framework of an existing organization, identify, pursue and encourage innovative opportunities and create a new organization, renewing the organization or introducing product and process innovations. (Vargas-Halabí et al. 2017:88)

Intrapreneurship is therefore the practice of entrepreneurship within an existing organisation, characterised by behavioural intentions departing from the customary (Coulthard \& Loos 2007; Kuratko \& Hodgetts 1995).

Despite large volumes of research on the topic, prominent authors in the field of intrapreneurship have noted a lack of consistency between definitions of intrapreneurship, 
suggesting that it is still in the process of determining its conceptual identity (Sandberg 2000; Sharma \& Chrisman 1999; Zahra 1991). Intra-organisational activities that can be classified as 'intrapreneurial' have been described through such terms as 'corporate entrepreneurship', 'intra-corporate entrepreneurship', 'corporate venturing' and 'internal corporate entrepreneurship' (Antončič \& Hisrich 2004; De Villiers-Scheepers 2012). Despite this array of differing terminologies attempting to label intrapreneurial activity, the scope can broadly be categorised into (1) the pursuit of entrepreneurial opportunity, (2) new market entry or (3) new venture creation (Gartner 1989; Lumpkin \& Dess 1996; Shane 2003). Common characteristics that can be found across these diverse terms include innovation, risk-taking and proactiveness. These traits are also traditionally associated with entrepreneurial actions (Antončič \& Hisrich 2001; Azami 2013; Stewart 2009). Although innovation is an integral component of both entrepreneurship and intrapreneurship, with Covin and Miles (1999:49) describing innovation as being 'at the center of the nomological network that encompasses the construct of corporate entrepreneurship', ongoing innovations within organisations should not necessarily be used synonymously with intrapreneurship. While maintaining a constant stream of product, service and process innovation is necessary to thrive in an increasingly competitive business environment, intrapreneurship is not simply equivalent with innovation. Intrapreneurship particularly concerns itself with the execution component of turning an innovation into a profitable business venture (Herve 2015). In addition, not all innovations originating from an organisation can be considered intrapreneurial, as this is dependent on where the idea originates from. Traditionally, in a corporate setting, ideas and product decisions are filtered from the top down, while in intrapreneurial organisations the idea for a new venture is likely to originate from the bottom up, that is, from any employee within the organisation (Haller 2015).

Despite these nuances, intrapreneurship can be the source of valuable contributions (Antončič \& Hisrich 2004). These contributions, as described in numerous studies, include improvements in organisational productivity and performance, increased profitability, increased revenue, higher growth, enhanced organisational innovativeness, development of new products, processes or technologies, as well as improved competitive positioning (Antončič \& Hisrich 2001; Bosma et al. 2012; Brizek 2014; Covin 1991; De Jong \& Wennekers 2008; Felício, Rodrigues \& Caldeirhina 2012; Gawke, Gorgievski \& Bakker 2017; Hastuti et al. 2015; Kacperczyk 2012; Zahra \& Covin 1995).

\section{Intrapreneurial orientation}

The dynamic nature of marketplaces, consumer behaviour and the rapidly changing competitive landscape place increasing importance on promoting intra-organisational processes that allow employees to transform opportunities into innovation (Hisrich \& Kearney 2012). Intrapreneurial orientation is vital for any business, but particularly so for small businesses, as it positively affects survival and competitiveness in the marketplace (Kakati 2003). An organisation's ability to harness intrapreneurial talent over a period of time builds internal capabilities, allowing the organisation to reinvent itself permanently, ultimately leading to improved performance and above-normal returns (Covin \& Slevin 1989; Felício et al. 2012; Hecker 2017; Lumpkin \& Dess 1996; Olokundun et al. 2017; Zahra 1991).

The increased focus on the employee as a source of innovation results in the recognition of the employee acting as an intrapreneur, with the skills, abilities and temperament to create value for the organisation by exploiting opportunities (Ma, Liu \& Karri 2016). The tendency of employees to act in an intrapreneurial manner is referred to as IO. Although IO can be characterised by a multitude of attitudes and behaviours, it is most commonly expressed in risk-taking propensity, innovativeness and proactiveness (Bolton \& Lane 2012; Matsuno, Mentzer \& Özsomer 2002; Sinha \& Srivastava 2015). As little research has been conducted on individual traits of IO, other studies propose alternative traits such as achievement orientation, autonomy, competitive aggressiveness and managerial skills (Goosen, De Coning \& Smit 2002; Luchsinger \& Bagby 1987; Lumpkin \& Dess 1996). While no universal agreement exists as to which individual-level factors foster IO, early evidence nonetheless indicates that $\mathrm{IO}$, in a varying combination of factors, has the potential to influence organisational growth. Accordingly, the following proposition is made:

$P^{1}$ : Intrapreneurial orientation positively relates to the internal growth of an SME.

In 2017, Schachtebeck conducted a systematic review of prominent Entrepreneurial Orientation (EO) and IO constructs, supported by a Delphi study with subject matter experts and semi-structured interviews with SME employees. Based on the study findings, he categorises IO into managerial factors and employee-related or 'personal elements' factors.

Schachtebeck (2017) identifies six managerial characteristics, which are similar to those proposed by Goosen et al. (2002). These characteristics include (1) intracapital (the provision of resources in spite of risk), (2) goals (future-oriented goal-setting), (3) intrapreneurship championing (support for intrapreneurship through structure, systems, processes and financial support), (4) rewards and innovation systems (rewarding desired goals and behaviours), (5) intrapreneurial freedom (empowerment of employees) and (6) communication (open channels of communication and information sharing).

The importance of support for IO at management level through championing, empowerment, autonomy, rewards and communication has been stressed in a number of studies (Fasnacht 2009; Goosen et al. 2002); however, at an individual 
level, the growth impact has not been explored. Based on these factors, the following propositions are made:

$P^{2}$ : Intracapital positively affects the internal growth of an SME.

$P^{3}$ : Goal-setting positively affects the internal growth of an SME.

$P^{4}$ : Intrapreneurship championing positively affects the internal growth of an SME.

$P^{5}$ : Reward and innovation systems positively affect the internal growth of an SME

$P^{6}$ : Intrapreneurial freedom positively affects the internal growth of an SME.

$P^{7}$ : Communication positively affects the internal growth of an SME.

In terms of personal elements factors, Schachtebeck (2017) identifies the following six qualities: (1) risk-taking propensity, (2) innovativeness, (3) proactiveness, (4) personal control (PC), (5) self-esteem (SE) and (6) achievement orientation. These IO-related elements are seen as bolstering SME growth. Risk-taking refers to the acceptance of uncertainty and tolerance of potential financial and reputational loss (Aarakit 2010; Goosen et al. 2002; Rauch et al. 2009). Innovativeness means willingness to engage in creative thinking in pursuit of novel discovery (Antonites \& Nonyane-Mathebula 2012; Miller 1983). Proactiveness is a future-oriented, opportunity-seeking mindset built on adaptability, in pursuit of competitive advantage (Alarape 2014; Urban 2012). Personal control refers to an employee's self-perception over the control of his or her work (Robinson et al. 1991). Self-esteem is an individual employee's selfbelief in his or her skills (Krishnan \& Kamalanabhan 2015; Robinson et al. 1991). Achievement orientation (AO) is an individual's interpretation and reaction to the success and growth of a venture (Choe \& Loo 2013; Jain, Ali \& Kamble 2015; Robinson et al. 1991). The proposed IO elements of risk-taking, innovativeness and proactiveness overlap with those used in a number of studies, most notably by Urban and Oosthuizen (2009), Bolton (2012), Bolton and Lane (2012) and Farrukh et al. (2017). On account of this literature, the following propositions are made:

\footnotetext{
$P^{8}$ : Individual employee risk-taking positively relates to internal growth of an SME.

$\boldsymbol{P}^{9}$ : Individual employee innovativeness positively relates to internal growth of an SME.

$P^{10}$ : Individual employee proactiveness positively relates to internal growth of an SME.
}

The remaining personal elements factors of IO, namely PC, $\mathrm{SE}$ and $\mathrm{AO}$, feature prominently in previous studies, notably those of Van Wyk and Boshoff (2004), Shetty (2004), Jain and Ali (2012) as well as Sinha and Srivastava $(2013,2015,2016)$. On the basis of these studies, the following propositions are suggested:

$P^{11}$ : Personal control positively relates to internal growth of an SME.

$P^{12}$ : Self-esteem positively relates to internal growth of an SME.

$P^{13}$ : Achievement orientation positively relates to internal growth of an SME.
The adapted measuring instrument is based on an integrated, conceptual framework crafted as part of an empirical study by Schachtebeck (2017). The conceptual framework, reflecting the propositions, personal elements and managerial factors described above, is depicted in Figure 1.

Intrapreneurial employees typically possess particular traits, such as creativity, risk-taking, patience, perseverance and proactiveness (Azami 2013). While the existence of these attitudes and traits in employees is a good point of departure for intrapreneurship, an enabling work environment is nonetheless necessary to foster IO. To harness these traits, management needs to resource, encourage and empower intrapreneurial employees (Azami 2013; Goosen et al. 2002; Sinha \& Srivastava 2015). Coetzer (2016) argues that an organisation that designs managerial strategies to foster IO in employees improves its chances of organisational success. The integrated conceptual framework captures the interplay between managerial and personal factors. The framework therefore proposes that for an SME to grow, both managers and employees contribute to developing an individual-level IO.

\section{Problem statement}

While the EO concept has been extensively researched and a connection has been drawn between EO and growth, IO has received markedly less attention, particularly in the South African context (Antončič \& Hisrich 2001; Stull 2005; Vargas-Halabí et al. 2017). In light of the low levels of EEA and TEA, as well as the small number of high-growth SMEs, a significant gap in the literature becomes apparent. Compounding this lack of information on IO within SMEs is the poor socio-economic situation of South Africa, characterised by high levels of unemployment, poverty and stagnant economic growth rates (Dessus et al. 2017). Nurturing the pool of high-growth SMEs undoubtedly holds potential for the South African economy; however, it is not known which IO factors positively relate to internal SME growth metrics. The purpose of this study is therefore to test an adapted measuring instrument for usability and feasibility as well as to collect preliminary data on the phenomenon in question. The adapted measuring instrument is developed based on the integrated conceptual framework as a basis. The preliminary data aim to explore the effects of IO-selected SME growth metrics, thereby indicating whether managerial factors and personal intrapreneurial factors of employees harbour the potential to further internal growth.

\section{Research methodology}

This section discusses the methodology used in the study. Instrument development, population, sample size calculation, data collection process, data analysis techniques, reliability and validity measures are discussed.

\section{Measuring instrument}

The measuring instrument is based on the integrated conceptual framework presented in Figure 1. The instrument 


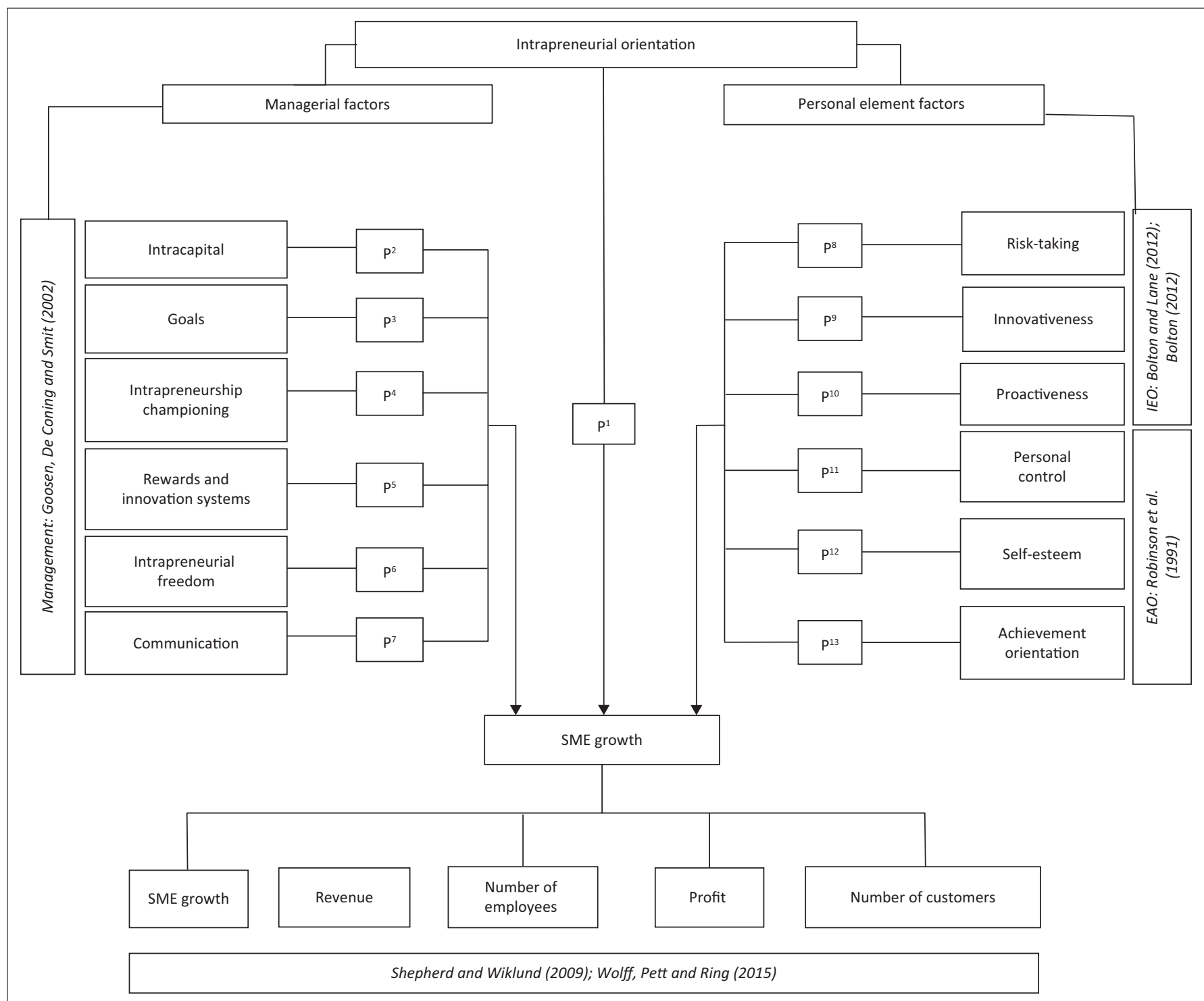

Source: Schachtebeck, C., 2017, 'Individual-level intrapreneurial orientation and organisational growth in small and medium enterprises', Unpublished doctoral thesis, Johannesburg, University of Johannesburg

FIGURE 1: Integrated conceptual framework.

contains two sections. Section A investigates key demographic variables, while Section B is concerned with $\mathrm{IO}$ variables. The instrument measures key factors of $\mathrm{IO}$ as per the conceptual framework, categorised according to managerial or personal factors. Managerial factors include intracapital, goal-setting, intrapreneurship championing, reward and innovation systems, intrapreneurial freedom and communication. Personal factors include risk-taking, proactiveness, innovativeness, $\mathrm{PC}, \mathrm{SE}$ and $\mathrm{AO}$. The instrument contains eight growth-related items in order to relate IO factors to SME growth, which are operationalised in five growth variables. The instrument, in total, contains 50 items on a five-point Likert scale to accurately measure strength of perception. The instrument adapts items from other wellknown instruments used in previous EO and IO studies. Management items (M1-M14) were adapted from Goosen et al. (2002); risk-taking (R1-R4), innovativeness (I1-I4) and proactiveness (P1-P5) were adapted from Bolton and Lane (2012); intrapreneurial orientation (IO1-IO3) was adapted from Stewart (2009); and personal control (PC1-PC4), selfesteem (SE1-SE4) and AO (AO1-AO4) were adapted from Robinson et al. (1991).

\section{Population}

The population of the study included SMEs in nine provinces of South Africa. While no reliable data currently exist as to how many SMEs exist in South Africa, it is estimated that between 700000 and 960000 registered businesses exist, with around 434000 of these reporting a loss or no taxable income (Absa SME Index 2014; Davis Tax Committee 2014; Finmark Trust 2010;). However, as the estimated number of businesses includes the informal sector, it is difficult to accurately gauge the exact size and extent of formal sector SMEs.

\section{Data collection}

Between November 2017 and January 2018, questionnaires were distributed both online, in Google Forms, and in hard 
copy. Hard copy questionnaires were administered in five South African provinces, while online questionnaires were sent to SMEs listed in a number of SME databases. The sampling frame included SMEs listed in YelloSA, Ezee-Dex and the Small Business Directory.

For both survey approaches, a probability sampling approach was followed in the form of simple random sampling. A total of 1421 questionnaires was distributed, with 332 responses being received, resulting in an overall response rate of $23.3 \%$. Of the 1421 questionnaires, 1091 were distributed online, yielding 72 responses, thereby resulting in a response rate of $6.6 \%$ for online responses. The remaining 330 questionnaires were distributed physically, yielding 260 responses, thereby resulting in a response rate of $78.8 \%$ for physical distribution. Twenty physical questionnaires were excluded from the analysis because of missing pages, while a further 22 questionnaires were regarded as invalid and thus excluded from final analysis as they were completed by owners of SMEs, therefore not falling within the target population. A total yield of 290 valid responses was therefore obtained.

\section{Data analysis}

Data were captured on Microsoft Excel and imported into the Statistical Package for Social Science (SPSS) version 25. SPSS software was used to analyse the data and generate statistics. Data analysis techniques included tests for reliability, sample adequacy, descriptive statistics, exploratory factor analysis (EFA), correlation analysis and regression analysis.

Descriptive statistics include means, standard deviation (SD) and percentages of key demographic variables. In the factor analysis, principal component analysis (PCA) was used to transform the original variables into a smaller set of linear combinations, 'with all the variance in the variables being used' (Pallant 2016:183). This yielded a new group of related factors. To determine correlation, Pearson's product-moment correlation coefficient $(r)$ was utilised, as it is the most frequently utilised technique as a measure of association, thereby indicating the strength of relationships between two variables (Pallant 2016; Tabachnick \& Fidell 2007). A standard multiple regression analysis was performed, indicating how a set of independent variables predicts a dependent variable, namely SME growth (Pallant 2016). To test sample adequacy and the factorability of data, Bartlett's test of sphericity and the Kaiser-Meyer-Olkin (KMO) measure of sampling adequacy were utilised. Bartlett's test of sphericity should be significant $(p<0.05)$ for factor analysis to be deemed appropriate, while KMO should be $>0.6$ (Pallant 2016).

\section{Reliability and validity}

Reliability of the measuring instrument was determined by means of Cronbach's alpha $(\alpha)$, which was used to analyse the internal consistency of the sub-scales. A value of 0.7 is most commonly regarded as an acceptable level of internal reliability (DeVellis 2012; Malhotra 2010). Content validity of the measuring instrument was established by pretesting the questionnaire with four academics and seven employees of SMEs at various levels to ensure representativeness of the study population. Question wording and formatting was adapted before commencement of the study.

\section{Ethical considerations}

The front page of the questionnaire informed respondents about their rights, emphasising the voluntary nature of the research, the right of withdrawal at any time as well as the assurance of confidentiality and anonymity. No identifying information, other than basic demographic data such as age and gender, was collected in the course of the research. Ethical clearance for the study was obtained from the College of Business and Economics at the University of Johannesburg (ethical clearance number: FOM2017-BM065).

\section{Findings}

Firstly, the demographic variables obtained from the study are presented, followed by an initial reliability analysis. Next, a factor analysis is conducted, followed by the findings from the correlation and regression analyses.

\section{Demographics}

The results of the demographic profile of the respondents are presented in Table 1.

The demographic variables indicate that, in terms of gender, the sample of 290 respondents was almost equally distributed, as 149 were male $(51.4 \%)$ and 141 were female respondents $(48.6 \%)$. The majority of respondents were between the ages of 18 and 30 years (37.2\%) and 31 and 40 years (36.6\%), with the remainder being above the age of 41 years. No respondents were below the age of 18 years. While responses were received from all nine provinces, the majority originated from the economic powerhouse of South Africa, Gauteng (60.7\%), followed by Mpumalanga (17.2\%), North-West province $(6.9 \%)$, Western Cape (5.5\%), Free State (3.1\%) and Limpopo (2.8\%). In terms of race, the majority of the sample were black people $(58.3 \%)$, followed by white people $(25.5 \%)$, mixed race people $(9.0 \%)$ and Indian/Asian population $(5.9 \%)$. In terms of education, most of the respondents had a matric (school leaving) certificate (49.3\%), 22.1\% had an undergraduate degree and $15.5 \%$ had postgraduate degrees. The remainder of the respondents $(13.1 \%)$ indicated basic schooling as their highest level of education. For length of service, most of the respondents were employed between 1 and 5 years $(41.7 \%)$, followed by 6 and 10 years $(24.1 \%)$ and more than 10 years (15.2\%), thereby demonstrating good institutional knowledge. Of the respondents, 19\% were employed for less than 1 year. While all the respondents were employees, a majority of them occupied nonmanagerial positions (48.3\%), followed by middle, lower and top management positions, at $22.4 \%, 18.6 \%$ and $10.7 \%$, respectively. From an organisational point of view, most of the SMEs in the sample were small businesses, employing between 5 and 20 employees (36.2\%), 21-50 employees (29\%) 
or less than 5 employees (9.3\%). A quarter of employees $(25.5 \%)$ reported working for a medium-sized business with more than 51 employees. Lastly, in terms of the sector the employees worked in, most of the respondents reported

TABLE 1: Demographic variables of the study population.

\begin{tabular}{|c|c|c|}
\hline \multirow[t]{2}{*}{ Variable } & \multicolumn{2}{|c|}{ Frequency } \\
\hline & $n$ & $\%$ \\
\hline \multicolumn{3}{|l|}{ Gender } \\
\hline Male & 149 & 51.4 \\
\hline Female & 141 & 48.6 \\
\hline \multicolumn{3}{|l|}{ Age } \\
\hline $18-30$ years & 108 & 37.2 \\
\hline $31-40$ years & 106 & 36.6 \\
\hline $41-50$ years & 53 & 18.3 \\
\hline $51+$ years & 23 & 7.9 \\
\hline \multicolumn{3}{|l|}{ Province } \\
\hline Gauteng & 176 & 60.7 \\
\hline Free State & 9 & 3.1 \\
\hline Eastern Cape & 3 & 1.0 \\
\hline Western Cape & 16 & 5.5 \\
\hline Northern Cape & 3 & 1.0 \\
\hline KwaZulu-Natal & 5 & 1.7 \\
\hline Limpopo & 8 & 2.8 \\
\hline Mpumalanga & 50 & 17.2 \\
\hline North-West province & 20 & 6.9 \\
\hline \multicolumn{3}{|l|}{ Race } \\
\hline Black people & 169 & 58.3 \\
\hline Indian/Asian people & 17 & 5.9 \\
\hline Mixed race people & 26 & 9.0 \\
\hline White people & 74 & 25.5 \\
\hline Other & 4 & 1.4 \\
\hline \multicolumn{3}{|l|}{ Highest level of education } \\
\hline Basic schooling & 38 & 13.1 \\
\hline Matric & 143 & 49.3 \\
\hline Undergraduate degree & 64 & 22.1 \\
\hline Postgraduate degree & 45 & 15.5 \\
\hline \multicolumn{3}{|l|}{ Length of service (current employer) } \\
\hline$<1$ year & 55 & 19.0 \\
\hline $1-5$ years & 121 & 41.7 \\
\hline $6-10$ years & 70 & 24.1 \\
\hline $10+$ years & 44 & 15.2 \\
\hline \multicolumn{3}{|l|}{ Position } \\
\hline Non-managerial employee & 140 & 48.3 \\
\hline Lower management & 54 & 18.6 \\
\hline Middle management & 65 & 22.4 \\
\hline Top management & 31 & 10.7 \\
\hline \multicolumn{3}{|l|}{ Number of employees in organisation } \\
\hline$<5$ employees & 27 & 9.3 \\
\hline 5-20 employees & 105 & 36.2 \\
\hline 21-50 employees & 84 & 29.0 \\
\hline $51+$ employees & 74 & 25.5 \\
\hline \multicolumn{3}{|l|}{ Sector/subsector } \\
\hline Agriculture & 9 & 3.1 \\
\hline Mining and quarrying & 10 & 3.4 \\
\hline Manufacturing & 42 & 14.5 \\
\hline Electricity, gas and water & 10 & 3.4 \\
\hline Construction & 14 & 4.8 \\
\hline Retail motor trade and repair services & 21 & 7.2 \\
\hline Wholesale trade, commercial agents and allied services & 29 & 10.0 \\
\hline Catering, Accommodation and other trade & 45 & 15.5 \\
\hline Transport, storage and communications & 39 & 13.4 \\
\hline Finance and business services & 42 & 14.5 \\
\hline Community, social and personal services & 29 & 10.0 \\
\hline
\end{tabular}

working in the catering and accommodation industry (15.5\%), followed by manufacturing and finance and business services (both 14.5\%). The remainder of the respondents reported working in a number of different industries, such as agriculture or construction.

\section{Pre-exploratory factor analysis reliability analysis}

Cronbach's alpha was used to measure the internal consistency of the measuring instrument, with the original constructs prior to the factor analysis. Cronbach's alpha for each underlying construct was computed to determine whether each construct displayed internal consistency. The findings are presented in Table 2.

While a Cronbach's alpha coefficient of above 0.7 is commonly accepted as indicating good internal consistency, it is sensitive to the number of items in a scale, particularly for scales with fewer than 10 items where low coefficients (0.5) are common (Pallant 2016). In cases where a scale contains fewer than 10 items, reporting the mean inter-item correlation is recommended, with a minimum value of 0.2 considered as acceptable (Briggs \& Cheek 1986; Pallant 2016).

As indicated in Table 2, proactiveness (0.760), IO (0.704), growth (0.829), PC (0.708) and management (0.873) all display a Cronbach's alpha coefficient of greater than 0.7, thereby indicating good internal consistency. Risk-taking, innovativeness, $\mathrm{AO}$ and SE record a Cronbach's alpha coefficient of $0.626,0.685,0.662$ and 0.528 , respectively. Because of the sub-scales each containing only four items, mean inter-item correlation values are reported. The mean inter-item correlation values for risk-taking (0.294), innovativeness (0.354), AO (0.333) and SE (0.278) are all above the 0.2 threshold, thereby indicating adequate internal consistency. A second reliability analysis is presented postEFA, reflecting reliability scores of newly emerging and combined factors.

\section{Exploratory factor analysis}

Bartlett's test of sphericity was used to determine the factorability of data, while KMO was used to test for sampling adequacy. The recorded KMO value was 0.825 , which was above the threshold minimum value of 0.6 , thereby indicating that the data are suitable for factor analysis. Bartlett's test of

TABLE 2: Pre-exploratory factor analysis reliability analysis.

\begin{tabular}{lccc}
\hline Construct & $\begin{array}{c}\text { Cronbach's } \\
\text { alpha }\end{array}$ & $\begin{array}{c}\text { Number of } \\
\text { items }\end{array}$ & $\begin{array}{c}\text { Mean inter-item } \\
\text { correlation }\end{array}$ \\
\hline Risk-taking & 0.626 & 4 & 0.294 \\
Innovativeness & 0.685 & 4 & 0.354 \\
Proactiveness & 0.760 & 5 & 0.397 \\
Achievement orientation (AO) & 0.662 & 4 & 0.333 \\
Self-esteem (SE) & 0.528 & 4 & 0.278 \\
Personal control (PC) & 0.708 & 4 & 0.384 \\
Intrapreneurial orientation (IO) & 0.704 & 3 & 0.449 \\
Growth & 0.829 & 8 & 0.392 \\
Management & 0.873 & 14 & 0.331 \\
\hline
\end{tabular}


sphericity, at 0.000 , is significant at $p<0.05$, thereby indicating that factor analysis is appropriate for the data set.

Next, factor extraction was performed by means of PCA. In the decision-making process regarding which items or variables to retain, Kaiser's criterion, known as the eigenvalue rule, was used to only retain factors with an eigenvalue of 1 or more.

In the factor extraction process, an unrotated factor solution was selected. Direct oblimin was chosen as the rotation method. The initial PCA showed the presence of 10 factors, with eigenvalues of 1.14 and above, explaining 19.8\%, 9.2\%, $5.8 \%, 4.4 \%, 3.5 \%, 3.3 \%, 2.7 \%, 2.6 \%, 2.5 \%$ and $2.4 \%$ of the variance, respectively. As the pattern matrix indicated significant cross-loading and an unclear pattern structure, a number of items were removed to obtain a clearer pattern. After removing items SE1, SE2, M5, M12, M13, M14, P1, I2, I4, PC4 and A4, a seven-component solution was obtained, explaining $53.140 \%$ of the variance.
The rotated solution indicated the presence of a simpler structure, with seven factors displaying strong loadings (above 0.3) and associated items loading against the seven factors. The pattern matrix with the seven-component solution is shown in Table 3.

Table 3 indicates that six of the original factors loaded under three new distinct variables, contrary to the original framework. The three new distinct variables consisted of (1) proactiveness and $\mathrm{AO}$, (2) risk-taking and innovativeness and (3) PC and SE. Furthermore, the 'management' construct was split into two variables, consisting of (1) M6-11 and (2) M1-M4. The table further shows commonalities for each item, outlining how much of the variance in each item is explained. Values below 0.3 indicate a poor fit with the other items in a component (Pallant 2016). All values for commonalities are above the 0.3 threshold, thereby indicating adequate fit of items for each component.

TABLE 3: Pattern matrix.

\begin{tabular}{|c|c|c|c|c|c|c|c|c|}
\hline \multirow[t]{2}{*}{ Variable } & \multicolumn{8}{|c|}{ Component } \\
\hline & $\begin{array}{l}\text { Proactiveness } \\
\text { and } \mathrm{AO}\end{array}$ & $\begin{array}{l}\text { Management-led } \\
\text { activities }\end{array}$ & Growth & $\begin{array}{l}\text { Risk-taking and } \\
\text { innovativeness }\end{array}$ & PC and SE & 10 & INT & Communalities \\
\hline P3 & 0.669 & - & - & - & - & - & - & 0.547 \\
\hline P5 & 0.659 & - & - & - & - & - & - & 0.548 \\
\hline A1 & 0.656 & - & - & - & - & - & - & 0.476 \\
\hline P2 & 0.639 & - & - & - & - & - & - & 0.498 \\
\hline P4 & 0.632 & - & - & - & - & - & - & 0.603 \\
\hline $\mathrm{A} 2$ & 0.528 & - & - & - & - & - & - & 0.444 \\
\hline A3 & 0.441 & - & - & - & - & - & - & 0.345 \\
\hline M7 & - & 0.762 & - & - & - & - & - & 0.578 \\
\hline M8 & - & 0.749 & - & - & - & - & - & 0.652 \\
\hline M6 & - & 0.683 & - & - & - & - & - & 0.561 \\
\hline M9 & - & 0.617 & - & - & - & - & - & 0.565 \\
\hline M11 & - & 0.604 & - & - & - & - & - & 0.520 \\
\hline M10 & - & 0.538 & - & - & - & - & -0.304 & 0.522 \\
\hline G1 & - & - & -0.779 & - & - & - & - & 0.635 \\
\hline G5 & - & - & -0.734 & - & - & - & - & 0.572 \\
\hline $\mathrm{G} 2$ & - & - & -0.728 & - & - & - & - & 0.582 \\
\hline G4 & - & - & -0.705 & - & - & - & - & 0.502 \\
\hline G3 & - & - & -0.627 & - & - & - & - & 0.552 \\
\hline G8 & - & - & 0.597 & - & - & - & - & 0.486 \\
\hline G7 & - & - & -0.592 & - & - & - & - & 0.532 \\
\hline G6 & - & - & -0.561 & - & - & - & - & 0.355 \\
\hline R2 & - & - & & 0.685 & - & - & - & 0.550 \\
\hline R1 & - & - & & 0.665 & - & - & - & 0.436 \\
\hline R3 & - & - & & 0.627 & - & - & - & 0.470 \\
\hline 11 & - & - & & 0.585 & - & - & - & 0.449 \\
\hline 13 & - & - & & 0.475 & - & - & - & 0.384 \\
\hline R4 & - & - & - & 0.337 & - & - & - & 0.395 \\
\hline PC3 & - & - & - & - & -0.760 & - & - & 0.577 \\
\hline PC2 & - & - & - & - & -0.691 & - & - & 0.551 \\
\hline SE4 & - & - & - & - & -0.655 & - & - & 0.528 \\
\hline SE3 & - & - & - & - & -0.566 & - & - & 0.502 \\
\hline PC1 & - & - & - & - & -0.562 & - & - & 0.576 \\
\hline 102 & - & - & - & - & - & -0.790 & - & 0.677 \\
\hline 103 & - & - & - & - & - & -0.712 & - & 0.600 \\
\hline 101 & - & - & - & - & - & -0.708 & - & 0.591 \\
\hline M4 & & - & - & - & - & - & -0.716 & 0.584 \\
\hline M2 & & - & - & - & - & - & -0.657 & 0.625 \\
\hline M1 & & - & - & - & - & - & -0.600 & 0.568 \\
\hline M3 & - & - & - & - & - & - & -0.578 & 0.590 \\
\hline
\end{tabular}

AO, achievement orientation; IO, intrapreneurial orientation; INT, interpersonal activities. 
Literature suggests that proactiveness and $\mathrm{AO}$ are closely related, as the purpose of proactiveness is the pursuit of a 'first-mover' advantage, in itself a form of achievement, while achievement implies impact and perseverance through proactive actions (Bateman \& Crant 1993, 1999; Frese et al. 2007). This factor is referred to as proactive achievement (PA).

Risk-taking and innovation (RI) are usually deemed distinct concepts in entrepreneurial literature (Lumpkin \& Dess 1996; Miller 1983; Stewart 2009). Some studies however suggest that, specifically at an individual level, RI form part of a combination of personality traits and therefore should not be considered separately, as they tend to provide a weak indication of an individual's propensity to act in an entrepreneurial manner (Bolton \& Lane 2012; Zhao \& Seibert 2006; Zhao, Seibert \& Lumpkin 2010). At an individual level, the pursuit of innovation involves an element of risk and can fluctuate in the individual employee based on past successes and failures (Harris \& Gibson 2008; Robinson et al. 1991). This factor is referred to as RI.

Items from an instrument developed by Robinson et al. (1991) were used in this study and it is these authors who, most prominently, postulate that PC and SE are distinct individual factors positively affecting business outcomes. This view is supported by other authors, such as Van Wyk and Boshoff (2004), Sharif and Saud (2009) and Krishnan and Kamalanabhan (2015). In the South African context, this scale presented similar results for PC and SE. Boshoff and Hoole (1998) attribute this finding to intercultural differences between the North American and South African contexts. Similar findings, with constructs deviating from the original instrument, can be seen in other South African studies (Boshoff \& Scholtz 1995; Van Wyk, Boshoff \& Kruger 2004). This factor is referred to as personal control and self-esteem (PCSE).

Lastly, the split in the managerial items can be attributed to phrasing in the underlying scale, supported by findings seen during initial scale development (Goosen et al. 2002), with items M1-M4 referring to management-controlled activities (such as goal-setting, rewards and innovation systems, and intracapital) and items M6-M11 containing managementcontrolled activities (such as intrapreneurial freedom, communication and championing). Items M1-M4 contain management-related items that are more prescriptive and management-led in nature, while M6-M11 contain items involving interpersonal activities. The two managerial factors are referred to as management-led activities (MGT) and interpersonal activities (INT), respectively.

\section{Post-exploratory factor analysis reliability analysis}

A second reliability analysis measured internal consistency of the new factors determined through the EFA. The Cronbach's alpha for new constructs is shown in Table 4.
TABLE 4: Post-exploratory factor analysis reliability analysis.

\begin{tabular}{lccc}
\hline Construct & $\begin{array}{c}\text { Cronbach's } \\
\text { alpha }\end{array}$ & $\begin{array}{c}\text { Number } \\
\text { of items }\end{array}$ & $\begin{array}{c}\text { Mean inter-item } \\
\text { correlation }\end{array}$ \\
\hline Proactive achievement (PA) & 0.804 & 7 & 0.373 \\
Management-led activities (MGT) & 0.776 & 4 & 0.464 \\
Interpersonal activities (INT) & 0.813 & 6 & 0.423 \\
Risk-taking and innovation (R \& I) & 0.707 & 6 & 0.289 \\
Intrapreneurial orientation (IO) & 0.704 & 3 & 0.449 \\
Personal control and self-esteem (PCSE) & 0.770 & 5 & 0.409 \\
Growth & 0.829 & 8 & 0.392 \\
\hline
\end{tabular}

For the newly determined constructs, all Cronbach's alpha coefficients were above the threshold value of 0.7 , an improvement from the pre-EFA reliability analysis. All mean inter-item correlations were above the threshold value of 0.2 .

\section{Correlation analysis}

The relationship between growth and proposed underlying IO constructs was investigated using Pearson productmoment correlation coefficient. Prior to the correlation analysis, a preliminary analysis was conducted to check for violation of assumptions of homoscedasticity, linearity and normality. The results of the correlation analysis, together with the means and SDs for the underlying factors, are presented in Table 5.

Table 5 indicates that at the 0.01 level, a statistically significant, positive linear correlation exists between growth and the factors PA, MGT, INT, RI, PCSE and IO. It should, however, be noted that while a statistically significant linear correlation between two factors may exist, effect size needs to be considered to interpret practical significance (Elliott \& Woodward 2016). Effect sizes are considered trivial when $r<0.10$, small for $r$ between 0.10 and 0.29, medium for $r$ between 0.30 and 0.49 and large for $r$ greater than 0.50 (Cohen 1988; Elliott \& Woodward 2016). The factors PA, INT, RI, PCSE and IO indicate $r$ of $0.238,0.260,0.247,0.198$ and 0.184 , respectively. This indicates that while statistically significant, the strength of the relationship between these variables and growth is considered small. The strength of the relationship between MGT and growth can be considered medium because of an $r$ value of 0.313 .

\section{Regression analysis}

An initial standard multiple regression analysis was performed to assess the ability of all independent variables (PA, MGT, INT, RI, PCSE and IO) to predict growth. An analysis to ensure no violation of the assumptions of normality, linearity, multicollinearity and homoscedasticity was conducted. No major deviations from normality could be observed. No multicollinearity was found as all tolerance values were above 0.1 and all variance inflation factor (VIF) values were below 10 (Pallant 2016). Mahalanobis distances, at a maximum of 22.4, were below the critical value of 22.46 (Tabachnick \& Fidell 2013), thereby indicating no critical outliers. Cook's distance at 0.044 , below the critical value of 1 (Pallant 2016), confirmed the indications provided by the Mahalanobis distances, indicating no undue influence of 
TABLE 5: Pearson's product-moment correlation.

\begin{tabular}{|c|c|c|c|c|c|c|c|c|}
\hline \multicolumn{2}{|c|}{ Pearson correlation } & \multirow{2}{*}{$\begin{array}{c}\text { Growth } \\
1.00\end{array}$} & \multirow{2}{*}{$\begin{array}{c}\text { PA } \\
0.238\end{array}$} & \multirow{2}{*}{$\begin{array}{c}\text { MGT } \\
0.313\end{array}$} & \multirow{2}{*}{$\begin{array}{c}\text { INT } \\
0.260\end{array}$} & \multirow{2}{*}{$\frac{\mathbf{R I}}{0.247}$} & \multirow{2}{*}{$\begin{array}{l}\text { PCSE } \\
0.198\end{array}$} & \multirow{2}{*}{$\frac{10}{0.184}$} \\
\hline Growth & Pearson correlation & & & & & & & \\
\hline & Sig. (2-tailed) & & 0.000 & 0.000 & 0.000 & 0.000 & 0.001 & 0.002 \\
\hline & Mean & 3.89 & 4.390 & 3.620 & 3.670 & 3.920 & 4.460 & 3.660 \\
\hline & SD & 0.73 & 0.560 & 0.950 & 0.850 & 0.660 & 0.610 & 0.910 \\
\hline
\end{tabular}

$\mathrm{PA}$, proactive achievement; MGT, management-led activities; INT, interpersonal activities; RI, risk-taking and innovation; PCSE, personal control and self-esteem; IO, intrapreneurial orientation; SD, standard deviation.

TABLE 6: Initial regression analysis summary.

\begin{tabular}{lcccccccc}
\hline Variable & $\boldsymbol{B}$ & $\boldsymbol{t}$ & Sig. & \multicolumn{2}{c}{$\begin{array}{c}95.0 \% \text { Confidence } \\
\text { interval for B }\end{array}$} & \multirow{2}{*}{ Tolerance } & VIF \\
\cline { 5 - 7 } & & & & & Lower bound & Upper bound & & \\
\hline (Constant) & - & 3.439 & 0.001 & 0.576 & 2.119 & - & - \\
PA & 0.073 & 1.031 & 0.303 & -0.089 & 0.284 & 0.588 & 1.699 \\
Mgt1 & 0.200 & 3.025 & 0.003 & 0.054 & 0.256 & 0.675 & 1.482 \\
Mgt2 & 0.095 & 1.475 & 0.141 & -0.028 & 0.194 & 0.708 & 1.412 \\
RI & 0.112 & 1.770 & 0.078 & -0.014 & 0.262 & 0.745 & 1.341 \\
PCSE & 0.117 & 1.705 & 0.089 & -0.024 & 0.337 & 0.625 & 1.600 \\
IO & 0.017 & 0.266 & 0.790 & -0.085 & 0.112 & 0.763 & 1.310
\end{tabular}

Dependent variable: Growth.

$R=0.412 ; R$ square $=0.17 ;$ Adjusted $R$ square $=0.152 ;$ Standard error of estimate $=0.67569$. PA, proactive achievement; MGT1, management-led activities; MGT2, interpersonal activities; $\mathrm{RI}$, risk-taking and innovation; PCSE, personal control and self-esteem; IO, intrapreneuria orientation; VIF, variance inflation factor.

outliers on the model. A summary of the initial regression analysis including all constructs is presented in Table 6 .

Table 6 indicates that $17 \%$ of variance $\left(R^{2}=0.17\right)$ in the dependent variable (growth) is explained by the model (all independent variables). Of the independent variables in the model, only MGT was statistically significant $(p<0.05)$. The beta coefficients indicate that MGT $(B=0.200)$ makes the strongest unique contribution in explaining growth. All other variables record $p>0.05$, thereby indicating that the other variables do not make a unique contribution to growth.

A further regression analysis was conducted to achieve a parsimonious model. A parsimonious model aims to accomplish a desired level of prediction based on as few predictor variables as possible in order to discriminate the signal from the noise, thereby allowing better predictability and generalisation of a data set (Vandekerckhove, Matzke \& Wagenmakers 2015). Constructs were removed from the secondary regression analysis in the order of least significance based on observed $p$-values in each iteration. In order of removal, the constructs included IO, INT and PA, which were found not to be significant in any of the iterations. $P^{10}$ and $P^{13}$ are therefore not supported, as proactiveness and $\mathrm{AO}(p=0.303)$ do not positively relate to internal growth. $P^{4}$, $P^{6}$ and $P^{7}$ are therefore also not supported, as the INT ( $p=0.141)$, containing the elements intrapreneurial freedom, communication and intrapreneurial championing, does not positively relate to internal growth. After three iterations, a regression model highlighting significant IO constructs was obtained, thereby achieving a parsimonious model. The results of the final iteration are presented in Table 7.

The same analysis as for the initial regression analysis was conducted to ensure no violation of the assumptions of normality, linearity, multicollinearity and homoscedasticity.
TABLE 7: Final regression analysis summary.

\begin{tabular}{lccccccc}
\hline Variable & $\boldsymbol{B}$ & $\boldsymbol{t}$ & Sig. & \multicolumn{2}{c}{$\begin{array}{c}\mathbf{9} 5.0 \% \text { Confidence } \\
\text { interval for B }\end{array}$} & Tolerance & VIF \\
\cline { 5 - 7 } & & & & $\begin{array}{l}\text { Lower bound } \\
\text { Upper bound }\end{array}$ & & \\
\hline (Constant) & - & 4.476 & 0.000 & 0.879 & 2.259 & - & - \\
Mgt1 & 0.270 & 4.745 & 0.000 & 0.121 & 0.292 & 0.906 & 1.104 \\
RI & 0.127 & 2.144 & 0.033 & 0.011 & 0.268 & 0.831 & 1.204 \\
PCSE & 0.174 & 2.973 & 0.003 & 0.077 & 0.379 & 0.859 & 1.165 \\
\hline
\end{tabular}

Dependent variable: Growth

$R=0.418 ; R$ square $=0.174 ;$ Adjusted $R$ square $=0.166 ;$ Standard error of estimate $=0.66263$. MGT1, management-led activities; RI, Risk-taking and innovation; PCSE, personal control and self-esteem; VIF, variance inflation factor.

No major deviations from normality were observed. Tolerance values were above the critical level 0.1 and all VIF values did not exceed the critical level of 10. Mahalanobis distances, at a maximum of 15.367 , were below the critical value of 16.27 (Tabachnick \& Fidell 2013), thereby indicating no critical outliers. Cook's distance at 0.044 , below the critical value of 1 , confirmed the indications provided by the Mahalanobis distances, finding no undue influence of outliers on the model.

Table 7 indicates that $17.4 \%$ of variance $\left(R^{2}=0.174\right)$ in the dependent variable (growth) is explained by the model (all independent variables), marginally unchanged from the original solution, thereby indicating the quality of fit of the final model. The regression analysis found MGT ( $p=0.000)$, RI $(p=0.033)$ and PCSE $(p=0.003)$ to be statistically significant $(p<0.05)$. The beta coefficients indicate that MGT $(B=0.270)$ makes the strongest unique contribution in explaining growth, followed by PCSE $(B=0.174)$ and RI $(B=0.127)$. With regard to propositions, $P^{8}$ and $P^{9}$ are supported, as RI positively relate to the internal growth of an SME. Furthermore, $P^{11}$ and $P^{12}$ are supported, as PC and SE positively relate to the internal growth of an SME. In addition, $P^{2}, P^{3}$ and $P^{5}$ are supported as goal-setting, rewards and innovation systems, and intracapital positively relate to the internal growth of an SME. Lastly, with regard to $P^{1}$, only certain elements of an IO positively relate to the internal growth, namely MGT, PCSE and RI.

\section{Discussion}

As the focus of the study is individual employees' IO effect on growth, the results allow for two sets of conclusions to be made. Firstly, in terms of the composition of IO, the results of the factor analysis support the findings of other studies and include risk-taking, proactiveness and innovation (Aarakit 2010; Antončič \& Hisrich 2003; Dess \& Lumpkin 2005). Other studies have found the management of an organisation to be a component of IO, as is the case in this study (Fasnacht 2009; Goosen et al. 2002). Personal control, SE and AO were found 
to be the components of IO in the factor analysis, which is also supported by other studies (Krishnan \& Kamalanabhan 2015; Shariff \& Saud 2009; Robinson et al. 1991; Van Wyk \& Boshoff 2004). However, no other study has currently considered all of these elements as underlying constructs of $\mathrm{IO}$, particularly not in the configuration as presented in the factor analysis.

Secondly, in terms of the positive effects of RI on growth, the findings of this study are supported by a number of authors, both at an individual level (Aarakit 2010; Aarakit \& Kimbugwe 2015; Griffith, Noble \& Qimei 2006; Hisrich \& Peters 2002; Hostager et al. 1998) and at an organisational level (Kraus et al. 2011; Kumarpeli \& Semasinghe 2015; Stevenson \& Jarillo 1990; Wiklund \& Shepherd 2003). Proactiveness in this study, as in some other studies (Becherer \& Maurer 1999), was shown not to positively relate to growth, in contrast to other studies that found the opposite to be true (Hughes \& Morgan 2007; Kraus et al. 2011; Moreno \& Casillas 2008; Rauch et al. 2009; Soininen et al. 2012). As intrapreneurs are dependent on the organisation for the implementation and marketing of ideas, proactiveness is not always necessarily rewarded with results. In addition, while some studies generally regard PC, SE and $\mathrm{AO}$ as a set of factors positively influencing growth (Choe \& Loo 2013; Jain \& Ali 2012), this study found only PC and SE to positively influence growth. As with the proactiveness element, $\mathrm{AO}$ is generally intrinsic, but relies on the organisation for support and implementation. Lastly, in terms of managerial factors, intracapital, reward and innovation systems and goal-setting were found to positively influence growth, in line with the original developers of this subscale (Goosen et al. 2002). The important role of capital provision, reward for intrapreneurial efforts and importance of goal-setting has been widely acknowledged as the basis of entrepreneurial efforts (Booysens 2011; Nieman \& Nieuwenhuizen 2014; World Bank 2013). However, other managerially controlled factors, namely the championing of intrapreneurship, intrapreneurial freedom and communication, were not found to positively relate to growth, in contrast to the findings obtained in the original scale. Management will often curtail intrapreneurial efforts by reducing freedom and ceasing to communicate or champion risky efforts if associated business risk is deemed to be too great (Goosen et al. 2002; Robert \& Weiss 1988;). Management support is therefore crucial in setting an intrapreneurial scene, while the absence of it can curtail intrapreneurship (Macmillan, Block \& Narashima 1986; Pinchot 1985).

\section{Conclusion}

The purpose of this study was to assess the effects of IO on the internal growth of SMEs. The results of this study indicated that the adapted measuring instrument displays adequate internal consistency. In addition, the elements contained in the conceptual framework display statistically significant factor loadings, albeit in different configurations. When viewing these new configurations in light of SME growth, only risk-taking, innovation, PC, SE and certain managerial factors (goal-setting, reward and innovation, and intracapital) positively relate to SME growth. It therefore becomes apparent that only some IO elements positively relate to SME growth, while others display a lesser contribution to growth or none whatsoever.

The findings of this study hold potential for academia and industry alike. An in-depth insight into the IO phenomenon was gained and the body of knowledge expanded. Practically, after further testing, SMEs can use the instrument to identify areas of concern or pinpoint areas where improvements can be made, thereby enhancing organisational growth, profitability and competitiveness. This study has certain limitations. A much larger sample would yield more generalisable results. Furthermore, employees were defined as any individual, regardless of rank or seniority within the organisation. Additional insights may be gained from differentiating between employees at different levels within the organisation. Lastly, as the instrument and framework were designed for the South African context, the results cannot be generalised to settings in different countries. SMEs can alter internal policies in order to promote the factors that positively relate to growth, thereby better harnessing existing talent and increasing growth. Likewise, policymakers can benefit from the findings by not only focusing on the creation of SMEs, but also better developing and growing existing SMEs by promoting IOrelated factors in adapted policy frameworks.

Future studies should use the instrument in differing contexts to gauge areas for improvement in SMEs. Future studies should also be conducted longitudinally to map internal changes in IO relative to the evolution of an SME and its long-term effects on growth. As the underlying constructs were researched from a South African perspective, future studies should therefore be conducted outside the bounds of South Africa in a broader, African and emerging market.

\section{Acknowledgements Competing interests}

The authors declare that they have no financial or personal relationships that may have inappropriately influenced them in writing this article.

\section{Authors' contributions}

C.S. performed the fieldwork and write-up of the article. D.G. and C.N. acted as supervisors and provided critical input to the study.

\section{Funding}

This research received no specific grant from any funding agency in the public, commercial or not-for-profit sectors.

\section{Disclaimer}

The views and opinions expressed in this article are those of the authors and do not necessarily reflect the official policy or position of any affiliated agency of the authors. 


\section{References}

Aarakit, S.M., 2010, 'Intrapreneurial orientation, social networks and firm performance', Master's dissertation, Makerere University, Kampala, viewed 11 December 2017 from: http://makir.mak.ac.ug/handle/10570/1354.

Aarakit, S.M. \& Kimbugwe, F.K., 2015, 'The relationship between intrapreneurial orientation and firm performance', Global Advanced Research Journal of Social Science 4(1), 6-10

Abor, J. \& Quartey, P., 2010, 'Issues in SME development in Ghana and South Africa', International Research Journal of Finance and Economics 39(1), 218-228.

Absa SME Index, 2014, SME Index Report, viewed 11 December 2017, from http:// kzntopbusiness.co.za/site/user_data/files/ABSA_SME_Index_2014.pdf.

Alarape, A.A., 2014, 'Developing the entrepreneurial orientation of owner-managers of small and medium enterprises in Nigeria', Ife PsychologlA 22(1), 218-231.

Antončič, B. \& Hisrich, R.D., 2001, 'Intrapreneurship: Construct refinement and cross cultural validation', Journal of Business Venturing 16(5), 495-527. https://doi.org/ 10.1016/S0883-9026(99)00054-3

Antončič, B. \& Hisrich, R.D., 2003, 'Clarifying the Intrapreneurship concept', Journal of Small Business and Enterprise Development 10(1), 7-24. https://doi.org/10.1108/ 02621710410541114

Antončič, B. \& Hisrich, R.D., 2004, 'Corporate entrepreneurship contingencies and organizational wealth Creation', Journal of Management Development 23(6), 518-550. https://doi.org/10.1108/02621710410541114

Antonites, A.J. \& Nonyane-Mathebula, B.T., 2012, 'Engineers as entrepreneurs: Entrepreneurial orientation of engineers in South Africa', South African Journal of Industrial Engineering 23(1), 1-17.

Azami, S., 2013, 'Intrapreneurship - "an Exigent employment"', International Journa of Scientific \& Technology Research 2(4), 194-198.

Bateman, T.S. \& Crant, M.J., 1993, 'The proactive component of organizational behavior: A measure and correlates', Journal of Organizational Behavior 14(2), 103-118. https://doi.org/10.1002/job.4030140202

Bateman, T.S. \& Crant, M.J., 1999, 'Proactive behavior: Meaning, impact recommendations', Business Horizons 42(3), 1-11. https://doi.org/10.1016/ S0007-6813(99)80023-8

Becherer, R.C. \& Maurer, J.G., 1999, 'The proactive personality disposition and entrepreneurial behavior among small company presidents', Journal of Small Business Management 37(1), 28-37.

Blundell, R. \& Lockett, N. 2011, Exploring entrepreneurship: Practices and perspectives, Oxford University Press, New York, NY.

Bolton, D.L., 2012, 'Individual entrepreneurship orientation: Further investigation of a measurement instrument', Academy of Entrepreneurship Journal 18(1), 91-98.

Bolton, D.L. \& Lane, M.D., 2012, 'Individual entrepreneurial orientation: Development of a measurement instrument', Education + Training 54(2/3), 219-233.

Booysens, I., 2011, 'Are small, medium- and micro-sized enterprises engines of innovation? The reality in South Africa', Science and Public Policy 38(1), 67-78.

Boshoff, A.B. \& Hoole, C., 1998, 'Measuring entrepreneurial attitudes interculturally Is it possible?', South African Journal of Economic and Management Sciences 1(2), 234-253.

Boshoff, A.B. \& Scholtz, C.P.T., 1995, 'Measuring attitudes as a way of differentiating entrepreneurs?', South African Journal of Economic and Management Sciences 16(winter), 1-11.

Bosma, N., Stam, E. \& Wennekers, S. 2012, Entrepreneurial employee activity: A large scale international study, viewed 10 February 2018, from https://www.uu.nl/ sites/default/files/rebo_use_dp_2012_12-12.pdf.

Briggs, S.R. \& Cheek, J.M., 1986, 'The role of factor analysis in the development and evaluation of personality scales', Journal of Personality 54(1), 106-148. https:// doi.org/10.1111/j.1467-6494.1986.tb00391.x

Brigić, M. \& Umihanić, B., 2015, 'Intrapreneurship impact on growth of production companies in Bosnia and Herzegovina', Ekonomski Vjesnik 28(2), 393-408.

Brizek, M.G., 2014, 'Explaining corporate entrepreneurship: A contemporary literature investigation', Journal of Management and Marketing Research 14(1), 1-13.

Choe, K.L. \& Loo, S.C., 2013, 'An exploratory study on the relationship between entrepreneurial attitude and firm performance', Human Resource Management Research 3(1), 34-38.

Coetzer, G., 2016, 'An empirical examination of the mediating influence of time management on the relationship between adult attention deficit and role stress', Personnel Review 45(4), 681-706. https://doi.org/10.1108/PR-04-2015-0105

Cohen, J., 1988, Statistical power analysis for the behavioral sciences, Lawrence Earlbaum Associates, Hillsdale, MI.

Coulthard, C. \& Loos, J., 2007, Networking the missing link in firm based entrepreneurial orientation performance models, Working Paper Series, 1327-5216, Monash University, Department of Management, Melbourne.

Covin, J.G., 1991, 'Entrepreneurial vs. conservative firms: A comparison of strategies and performance', Journal of Management Studies 28(5), 439-462. https://doi. org/10.1111/j.1467-6486.1991.tb00763.x

Covin, J.G. \& Miles, M.P., 1999, 'Corporate entrepreneurship and the pursuit of competitive advantage', Entrepreneurship Theory and Practice 23(3), 47-63. https://doi.org/10.1177/104225879902300304

Covin, J.G. \& Slevin, D.P., 1989, 'Strategic management of small firms in hostile and benign environments', Strategic Management Journal 10(1), 75-87. https://doi. org/10.1002/smj.4250100107
Davis Tax Committee, 2014, Small and medium enterprises: Taxation considerations, Interim Report, Parliamentary Monitoring Group, Cape Town.

De Jong, J. \& Wennekers, S. 2008, 'Intrapreneurship - Conceptualizing entrepreneurial employee behavior', viewed 05 May 2017, from http://ondernemerschap.panteia. nl/pdf-ez/h200802.pdf.

De Villiers-Scheepers, M.J., 2012, 'Antecedents of strategic corporate entrepreneurship', European Business Review 24(5), 400-424. https://doi.org/10.1108/095553412 11254508

Dess, G.G. \& Lumpkin, G.T., 2005, 'The role of entrepreneurial orientation in stimulating effective corporate entrepreneurship', The Academy of Management Executive 19(1), 147-156.

Dessus, S.C., Goddard, J.G. \& Hanusch, M., 2017, South Africa economic update Innovation for productivity and inclusiveness, Washington, DC, viewed 12 February 2018, from http://documents.worldbank.org/curated/en/779551505322376708/ pdf/119695-WP-PUBLIC-SA-EU-2017-Digital-Version-Sep-19.pdf.

DeVellis, R.F., 2012, Scale development: Theory and applications, Sage, Thousand Oaks, CA.

Elliott, A.C. \& Woodward, W.A., 2016, IBM SPSS by example, Sage, Thousand Oaks, CA.

Farrukh, M., Chong, W.Y., Mansori, S. \& Ramzani, S.R., 2017, 'Intrapreneurial behaviour: The role of organizational commitment', World Journal of Entrepreneurship, Management and Sustainable Development 13(3), 1-27. https://doi.org/10.1108/ WJEMSD-03-2017-0016

Fasnacht, D. 2009, Open innovation in the financial services: Growing through openness, flexibility and customer integration, Springer-Verlag, Berlin.

Felício, J.A., Rodrigues, R. \& Caldeirhina, V.R., 2012, 'The effect of intrapreneurship on corporate performance', Management Decision 50(10), 1717-1738. https://doi. org/10.1108/00251741211279567

Finmark Trust, 2010, FinScope South Africa Small Business Survey 2010, viewed 14 February 2018, from http://www.finmark.org.za/wp-content/uploads/2016/01/ FS-Small-Business_-reportFNL2.pdf.

Frese, M., Krauss, S.I., Keith, N., Escher, S., Grabarkiewicz, R., Luneng, S.T. et al., 2007, 'Business owners' action planning and its relationship to business success in three African countries', Journal of Applied Psychology 92(6), 1481-98. https://doi. org/10.1037/0021-9010.92.6.1481

Gartner, W.B., 1989, 'Who is an entrepreneur? is the wrong question', Entrepreneurship Theory and Practice 13(4), 47-68. https://doi.org/10.1177/104225878901300406

Gawke, J., Gorgievski, M.J. \& Bakker, A.B., 2017, 'Personal costs and benefits of employee intrapreneurship: Disentangling the employee intrapreneurship, well-being, and job performance relationship', Journal of Occupational Health Psychology 23(4), 1-12.

Goosen, C.J., De Coning, T.J. \& Smit, E.v.d.M., 2002, 'Corporate entrepreneurship and financial performance: The role of management', South African Journal of Business Management 33(4), 21-27.

Griffith, D.A., Noble, S.M. \& Qimei, C., 2006, 'The performance implications of intrapreneurial proclivity: A dynamic capabilities approach', Journal of Retailing 82(1), 51-62. https://doi.org/10.1016/j.jretai.2005.11.007

Gruber-Muecker, T. \& Hofer, K.M., 2015, 'Market orientation, entrepreneurial orientation and performance in emerging markets', International Journal of Emerging Markets 10(3), 1-24.

Gürbüz, G. \& Aykol, S., 2009, 'Entrepreneurial management, entrepreneurial orientation and Turkish small firm growth', Management Research News 32(4), 321-336. https://doi.org/10.1108/01409170910944281

Haller, H.E., 2015, Intrapreneurship: Ignite innovation, Silver Eagle Press, Coeur d'Alene, ID.

Harris, M.L. \& Gibson, S.G., 2008, 'Examining the entrepreneurial attitudes of US business students', Education \& Training 50(7), 568-581. https://doi.org/10.1108/ 00400910810909036

Hastuti, A.W., Talib, N.B.A., Wong, K.Y. \& Mardani, A., 2015, 'The role of intrapreneurship for sustainable innovation through process innovation in small and medium-sized enterprises: A conceptual framework', International Journal of Economics and enterprises: A conceptual frame
Financial Issues 6(3S), 83-91.

Hecker, A., 2017, 'The intrapreneurial nature of organizational innovation: Toward a new process model', International Journal of Innovation 5(3), 375-398.

Herrington, M. \& Kew, J., 2017, Global entrepreneurship monitor global report 2016/17, viewed 20 December 2017, from http://gemconsortium.org/report.

Herrington, M., Kew, J. \& Mwanga, A., 2017, Global entrepreneurship monitor South Africa report 2016/17, viewed 20 December 2017, from http://gemconsortium. org/report.

Herve, G., 2015, Winning at Intrapreneurship, G3point0 Consulting, Beaconsfield.

Hisrich, R. \& Kearney, C., 2012, Corporate entrepreneurship: How to create a thriving entrepreneurial spirit throughout your company, McGraw-Hill, New York.

Hisrich, R.D. \& Peters, M.P. 2002, Entrepreneurship, McGraw-Hill/Irwin, Boston, MA.

Hostager, T.J., Neil, T.C., Decker, R.L. \& Lorentz, R.D., 1998, 'Seeing environmental opportunities: Effects of intrapreneurial ability, efficacy, motivation and desirability', Journal of Organizational Change Management 11(1), 11-25. https:// doi.org/10.1108/09534819810369536

Hughes, M. \& Morgan, R.E., 2007, 'Deconstructing the relationship between entrepreneurial orientation and business performance at the embryonic stage of firm growth', Industrial Marketing Management 36(5), 651-661. https://doi.org/ 10.1016/j.indmarman.2006.04.003

Jain, R. \& Ali, S.W., 2012, 'Entrepreneurial and intrapreneurial orientation in Indian enterprises: An empirical study', South Asian Journal of Management 19(3), 86-122. 
Jain, R., Ali, S.W. \& Kamble, S., 2015, 'Entrepreneurial and intrapreneurial attitudes: Conceptualization, measure development, measure test and model fit', Management and Labour Studies 40(1\&2), 1-21.

Kacperczyk, A.J., 2012, 'Opportunity structures in established firms: Entrepreneurship versus intrapreneurship in mutual funds', Administrative Science Quarterly 57(3), 484-521. https://doi.org/10.1177/0001839212462675

Kakati, M. 2003, 'Success criteria in high-tech new ventures', Technovation 23(5), 447-457. https://doi.org/10.1016/S0166-4972(02)00014-7

Kraus, S., Rigtering, J.P.C., Hughes, M. \& Hosman, V., 2011, 'Entrepreneurial orientation and the business performance of SMEs: A quantitative study from the Netherlands' Review of Managerial Science 6(2), 161-182. https://doi.org/10.1007/s11846 011-0062-9

Krishnan, L. \& Kamalanabhan, T.J., 2015, 'Entrepreneurial success and life satisfaction among women entrepreneurs in micro enterprises', South Asian Journal of Management 20(2), 40-63.

Kumarpeli, K.I. \& Semasinghe, D.M., 2015, 'The impact of entrepreneurial orientation on the growth of SMEs in Sri Lanka', Conference proceedings of the International Conference on Business, Marketing \& Information System Management held in Paris, France on 25-26 November 2015

Kuratko, D.F. \& Hodgetts, M.R., 1995, Entrepreneurship: A contemporary approach, [S.I.], Dryden Press, Hinsdale, IL.

Luchsinger, V. \& Bagby, D.R., 1987, 'Entrepreneurship and intrapreneurship: Behaviors, comparisons and contrasts', SAM Advanced Management Journal 52(3), 10-13.

Lumpkin, G.T. \& Dess, G.G., 1996, 'Clarifying the entrepreneurial orientation construct and linking it to performance', Academy of Management Review 21(1), 135-172. https://doi.org/10.5465/amr.1996.9602161568

Lyon, D.W., Lumpkin, G.T. \& Dess, G.G. 2000, 'Enhancing entrepreneurial orientation research: Operationalizing and measuring a key strategic decision-making process', Journal of Management 26(5), 1055-1085. https://doi.org/10.1177/01492063000 2600503

Ma, H., Liu, T.Q. \& Karri, R., 2016, 'Internal corporate venturing: Intrapreneurs, institutions and initiatives', Organizational Dynamics 45(2), 114-123. https://doi.org/ 10.1016/j.orgdyn.2016.02.005

MacMillan, I.C., Block, Z. \& Narashima. P.N.S., 1986, 'Corporate venturing: Alternatives, obstacles encountered and experience effects', Journal of Business Venturing 1(2), 177-191. https://doi.org/10.1016/0883-9026(86)90013-3

Malhotra, N.K. 2010, Marketing research: An applied orientation, New York, Pearson.

Matsuno, K., Mentzer, J.T. \& Özsomer, A., 2002, 'The effects of entrepreneurial proclivity and market orientation on business performance', Journal of Marketing proclivity and market orientation on business performance',

Miller, D., 1983, 'The correlates of entrepreneurship in three types of firms', Management Science 29(7), 770-791. https://doi.org/10.1287/mnsc.29.7.770

Moreno, A.M. \& Casillas, J.C., 2008, 'Entrepreneurial orientation and growth of SMEs: A causal mode', Entrepreneurship Theory and Practice 32(3), 507-528. https:// doi.org/10.1111/j.1540-6520.2008.00238.x

Nieman, G. \& Nieuwenhuizen, C. 2014, Entrepreneurship: A South African perspective, Van Schaik, Pretoria.

Nyström, K., 2012, Entrepreneurial employees: Are they different from independent entrepreneurs?, Working Paper Series in Economics and Institutions of Innovation 281, Royal Institute of Technology, CESIS - Centre of Excellence for Science and Innovation Studies, viewed 12 January 2018, from https://static.sys.kth.se/itm/ wp/cesis/cesiswp281.pdf.

Olokundun, M., Falola, H., Ibidunni, S., Ogunnaike, O., Peter, F. \& Kehinde, O., 2017, 'Intrapreneurship and innovation performance: A conceptual model', Academy of Strategic Management Journal 17(2), 1-5.

Pallant, J., 2016, SPSS survival manual, McGraw-Hill Education, New York.

Pinchot, G., 1985, Intrapreneuring, Harper \& Row, New York.

Rauch, A., Wiklund, J., Lumpkin, G.T. \& Frese, M., 2009, 'Entrepreneurial orientation and business performance: An assessment of past research and suggestions for the future', Entrepreneurship Theory and Practice 33(3), 761-787. https://doi.org/ 10.1111/j.1540-6520.2009.00308.x

Robert, M. \& Weiss, A., 1988, The innovation formula: How organisations turn change into opportunity, Cambridge, Ballinger, TX.

Robinson, P.B., Stimpson, D.V., Huefner, J.C. \& Hunt, H.K., 1991, 'An attitude approach to the prediction of entrepreneurship', Entrepreneurship Theory \& Practice 15(4), 13-31. https://doi.org/10.1177/104225879101500405

Rodríguez-Gutiérrez, M., Moreno, P. \& Tejada, P., 2015, 'Entrepreneurial orientation and performance of SMEs in the services industry', Journal of Organizational Change Management 28(2), 194-212. https://doi.org/10.1108/JOCM-01-20150020

Sandberg, J., 2000, 'Understanding human competence at work: An interpretive approach', Academy of Management Journal 43(1), 9-25.

Schachtebeck, C., 2017, 'Individual-level intrapreneurial orientation and organisational growth in small and medium enterprises', Unpublished doctoral thesis, Johannesburg, University of Johannesburg.

Shane, S., 2003, A general theory of entrepreneurship: The individual-opportunity nexus, Edward Elgar Publishing, Cheltenham.
Shariff, M.N. \& Saud, M.B., 2009, 'An attitude approach to the prediction of entrepreneurship on students at institution of higher learning in Malaysia', International Journal of Business and Management 4(1), 129-135. https://doi.org/ International Journal of B
$10.5539 /$ ijbm.v4n4p129

Sharma, P. \& Chrisman, J., 1999, 'Toward a reconciliation of the definitional issues in the field of corporate entrepreneurship', Entrepreneurship Theory and Practice 23(3), 11-27. https://doi.org/10.1177/104225879902300302

Shepherd, D.A. \& Wiklund, J., 2009, Entrepreneurial small business: A resource-based perspective, Edward Elgar Publishing, Northampton, MA.

Shetty, P., 2004, 'Attitude towards entrepreneurship in organizations', Journal of Entrepreneurship 13, 53-68. https://doi.org/10.1177/097135570401300103

Sinha, N. \& Srivastava, K.B.L., 2013, 'Association of personality, work values and sociocultural factors with intrapreneurial orientation', The Journal of Entrepreneurship 22(1), 97-113. Sinha, N. \& Srivastava, K.B.L., 2015, 'Intrapreneurship orientation and innovation championing in Indian organizations', Global Business Review 16(5), 760-771. https://doi.org/10.1177/0972150915591431

Sinha, N. \& Srivastava, K.B.L., 2016, 'Perceived innovation championing strategies and intrapreneurial orientation', Journal of Management Research 16(2), 77-86.

Slavec, A. \& Drnovsek, M., 2012, 'A perspective on scale development in entrepreneurship research', Economic and Business Review 14(1), 39-62.

Small Enterprise Development Agency (SEDA), 2017, SMME First Quarterly Survey of 2017, Small Enterprise Development Agency, Hatfield, Pretoria, viewed 12 February 2018, from http://www.seda.org.za/Publications/Publications/SMME\%20First $\% 20$ Quarterly\%202017_10102017.pdf.

Soininen, J., Martikainen, M., Puumalainen, K. \& Kyläheiko, K., 2012, ‘Entrepreneurial orientation: Growth and profitability of Finnish small- and medium-sized enterprises', International Journal of Production Economics 140(2), 614-621. https://doi.org/10.1016/j.ijpe.2011.05.029

Stevenson, H.H. \& Jarillo, J.C., 1990, 'A paradigm of entrepreneurial management', Strategic Management Journal 11(5), 17-27.

Stewart, J.K., 2009, 'An investigation of an intrapreneurial orientation among employees in service organisations', Doctoral thesis, Columbus, Ohio State University, viewed 15 May 2016, from http://rave.ohiolink.edu/etdc/view?acc num $=0$ osu1259109608.

Stull, M., 2005, 'Intrapreneurship in non-profit organizations: Examining the factors that facilitate entrepreneurial behavior among employees', Doctoral thesis, Cleveland Western Reserve University.

Tabachnick, B.G. \& Fidell, L.S., 2007, Using multivariate statistics, Pearson, New York. Tabachnick, B.G. \& Fidell, L.S., 2013, Using multivariate statistics, Pearson, New York.

Urban, B., 2012, 'The effect of pro-entrepreneurship architecture on organisational outcomes', Journal of Business Economics and Management 13(3), 518-545. https://doi.org/10.3846/16111699.2011.620153

Urban, B. \& Oosthuizen, C., 2009, 'Empirical analysis of corporate entrepreneurship in the South African mining industry', Journal of Contemporary Management 6(1), 170-192.

Van Wyk, R. \& Boshoff, A.B., 2004, 'Entrepreneurial attitudes: A distinction between two professional groups', South African Journal of Business Management 35(2), 33-38.

Van Wyk, R., Boshoff, A.B. \& Kruger, B.S., 2004, 'The relationship between entrepreneurial attitudes and demographic, occupational and organisational variables: A South African study', Management Dynamics 13(4), 15-25.

Vandekerckhove, J., Matzke, D. \& Wagenmakers, E. 2015, 'Model comparison and the principle of parsimony', in J.R. Busemeyer, Z. Wang, J.T. Townsend \& A. Eidels (eds.), The Oxford handbook of computational and mathematical psychology, pp. 300-319, Oxford University Press, New York.

Vargas-Halabí, T., Mora-Esquivel, R. \& Siles, B., 2017, 'Intrapreneurial competencies: Development and validation of a measurement scale', European Journal of Management and Business Economics 26(1), 86-111. https://doi.org/10.1108/ EJMBE-07-2017-006

Wiklund, J. \& Shepherd, D., 2003, 'Knowledge-based resources, entrepreneurial orientation and the performance of small and medium-sized businesses', Strategic Management Journal 24(13), 1307-1314. https://doi.org/10.1002/smj.360

World Bank, 2018, Global economic prospects: Sub-Saharan Africa analysis, viewed 10 March 2018, from http://pubdocs.worldbank.org/en/575011512062621151/ Global-Economic-Prospects-Jan-2018-Sub-Saharan-Africa-analysis.pdf

World Economic Forum, 2018, Europe's hidden entrepreneurs, viewed 10 March 2018, from http://www3.weforum.org/docs/WEF_Entrepreneurship_in_Europe.pdf.

Zahra, S.A., 1991, 'Predictors and financial outcomes of corporate entrepreneurship: an exploratory study', Journal of Business Venturing 6(4), 259-285.

Zahra, S.A. \& Covin, J.G., 1995, 'Contextual influences on the corporate entrepreneurship-performance relationship: A longitudinal analysis', Journal of

Zhao, H. \& Seibert, S., 2006, 'The big five personality dimensions and entrepreneurial status: A meta-analytic review', Journal of Applied Psychology 91(2), 259-271. https://doi.org/10.1037/0021-9010.91.2.259

Zhao, H., Seibert, S. \& Lumpkin, G.T., 2010, 'The relationship of personality to entrepreneurial intentions and performance: A meta-analytic review', Journal of Management 36(2), 381-404. https://doi.org/10.1177/0149206309335187 